\title{
Manajemen Strategi Pembelajaran Lembaga Anak Usia Dini Pada Masa Pandemi Covid-19
}

\author{
Abdul Aziz', Isfaroh ${ }^{2}$, Novi Kurnia Sari' ${ }^{3}$, Yulianto ${ }^{4}$ \\ 1,3,4Sekolah Tinggi Agama Islam Nahdlatul Ulama Purworejo, Indonesia \\ ${ }^{2}$ Universitas Islam Negeri Raden Mas Said Surakarta, Indonesia \\ radenaziz@ymail.com
}

\begin{abstract}
Abstrak
Pengelolaan lembaga anak usia dini perlu dikelola dengan baik agar menjadi sebuah lembaga berkualitas. Penelitian ini bertujuan mengkaji manajemen strategi pembelajaran lembaga pendidikan anak usia dini pada masa pandemi Covid-19. Metode penelitian ini menggunakan kualitatif, yaitu memakai data yang diperoleh dari hasil analisis di lapangan baik melalui observasi, wawancara maupun dokumentasi. Hasil penelitian menunjukkan adanya manajemen strategi yang diupayakan oleh kepala sekolah dalam mengelola risiko bencana di lembaganya. Kepala Sekolah TK Pertiwi 4 Giripurno Borobudur menerapkan manajemen strategi pembelajaran sebagai cara dalam rangka memperlancar proses pembelajaran di masa pandemi. Setidaknya ada empat strategi yang dilakukan TK Pertiwi 4 Giripurno dalam mengelola pembelajaran di era pandemi, di antaranya yaitu implementasi perencanaan yang matang melalui analisis manajemen krisis (before crisis, during crisis dan after crisis), pengorganisasian (organizing) lembaga yang tersistem, pelaksanaan (actuating) yang maksimal dan pemantauan (controlling) dengan menyesuaikan pada ketentuan perundang-undangan terkait situasi kondisi kedaruratan pandemi Covid-19. Melalui implementasi manajamen strategi tersebut, maka dapat menjadi strategi yang efektif dan efisien dalam mengendalikan proses pembelajaran walaupun di tengah kondisi krisis pandemi Covid-19.
\end{abstract}

Kata Kunci: manajemen strategi; pembelajaran; anak; masa pandemi

\section{Management Of Early Childhood Institution Learning Strategies During The Covid-19 Pandemic}

\begin{abstract}
The management of early childhood institutions needs to be managed properly in order to become a quality institution. This study aims to examine the management of learning strategies for early childhood education institutions during the Covid-19 pandemic. This research method uses qualitative, namely using data obtained from the results of analysis in the field either through observation, interviews and documentation. The results of the study indicate that there is a strategic management pursued by school principals in managing disaster risk in their institutions. The Principal of TK Pertiwi 4 Giripurno Borobudur applies learning strategy management as a way to expedite the learning process during the pandemic. There are at least four strategies in managing learning in the pandemic era, including the implementation of careful planning through analysis of crisis management (before crisis, during crisis and after crisis), systematic organization of institutions, maximum actuating and monitoring. controlling) by adjusting to statutory provisions related to the emergency situation of the Covid-19 pandemic. Through the implementation of this strategic management, it can be an effective and efficient strategy in controlling the learning process even in the midst of the Covid-19 pandemic crisis.
\end{abstract}

Keywords: strategic management; learning; child; pandemic era 


\section{PENDAHULUAN}

Dunia telah digegerkan dengan banyaknya pasien korban virus Covid-19 yang muncul pertama kali di Wuhan China pada akhir tahun 2019. Tidak perlu waktu lama bagi Covid-19 ini menyebar ke berbagai negara bahkan antar benua. Tepatnya pada 11 Februari 2020 World Health Organization (WHO) meresmikan virus ini dengan nama "Virus Corona" (Utomo, 2020). Kurang dari sebulan setelah peresmian tersebut diberlangsungkan, pada Maret 2020 hampir dua per tiga penduduk planet bumi dalam kondisi darurat Corona. Roda-roda kehidupan pun berjalan tersendat, roda ekonomi ngadat, disaat roda birokrasi melambat, rakyat pun semakin berpotensi melarat. Mata rantainya rumit dan panjang, semua bisa menjadi sebab dan sekaligus akibat. Tentu hal ini tidak dapat diselesaikan dengan cepat.

Oleh karenanya, tidaklah etis bagi seseorang yang berfikir bahwa seakan-akan masalah ini hanya lah masalah pribadinya sendiri, ia merasa sebagai seorang yang paling dirugikan dan paling menderita atas masalah ini. Padahal masalah ini adalah masalah seluruh bangsa manusia. Semua orang gelisah, waspada dan berupaya untuk menyelesaikan persoalan, dengan tanpa mengorbankan kepentingan orang lain. Dari tingkat masyarakat tertinggi sampai elemen terendah sedang melakukan hifdz al-nafs (menjaga keselamatan jiwa) agar bisa survive, bertahan hidup, yakni agar dapat hidup bersama seperti semula, bukan hidup sendiri dan menjaga jarak (social distancing) di planet bumi.

Pandemi Covid-19 berimplikasi pada seluruh aktivitas kehidupan manusia mulai aktivitas pendidikan (Fernandez \& Shaw, 2020), sosial, olahraga, perkantoran bahkan sampai pada hubungan spiritual-transedental bagi seluruh pemeluk agama di dunia. Covid-19 juga tidak pandang bulu dalam menyerang sektor kebutuhan utama manusia, yaitu sektor ekonomi dan pendidikan, terutama bidang pendidikan anak usia dini. Aktivitas pendidikan sebagai aktivitas yang dikenal lekat dengan interaksi yang melibatkan banyak orang, yaitu antara pendidik dengan peserta didik yang bertatap muka, menjadi diliburkan. Walaupun kemudian hari pemerintah melalui (Kementrian Pendidikan, 2020) memberikan solusi agar proses pembelajaran tetap berjalan, yakni dengan menerapkan Pembelajaran Jarak Jauh sampai pada jangka waktu yang belum ditentukan.

Pandemi Covid-19 juga berefek pada proses pendidikan yang seharusnya melalui interaksi secara langsung, menjadi dihentikan dan diganti dengan aktivitas pembelajaran jarak jauh (Rodrigues \& Franco, 2020) atau daring dengan memanfaatkan media internet. Hal ini berlaku untuk seluruh jenjang pendidikan mulai dari pendidikan anak usia dini, sekolah dasar, 
pendidikan menengah, pendidikan atas hingga perguruan tinggi (Stallman et al., 2021). Krisis global akibat pandemi Covid-19 ini juga berimplikasi pada merosotnya sikap kepemimpinan. Pentingnya sikap kepemimpinan bagi masyarakat diperlukan untuk menghadapi krisis ini. Sehingga diperlukan kepemimpinan untuk menyatukan pandangan orang dalam rangka memberikan penjelasan secara bijak tentang apa yang terjadi dan solusi apa yang diperlukan dalam mengendalikan pandemi (Haslam et al., 2021).

Seiring pertumbuhan lembaga pendidikan anak usia dini seperti Tempat Penitipan Anak (TPA), Bustanul Athfal (BA) / Kelompok Bermain (KB), Taman Kanak-kanak (TK)/ Raudlatul Athfal (RA), serta selaras dengan meningkatnya animo masyarakat yang tinggi, namun masih kurang diimbangi dengan manajemen penyelenggaraan PAUD yang dilaksanakan secara profesional. Selain itu, pembinaan dan perhatian pemerintah dalam alokasi anggaran pendidikan untuk anak usia dini juga masih rendah. Sehingga berimplikasi pada rendahnya kualitas sekaligus kuantitas manajemen lembaga yang professional. Di masa kehidupan normal -sebelum muncul pandemi Covid-19- manajemen lembaga PAUD juga belum menunjukkan eksistensinya secara total sebagai lembaga pendidikan yang fokus pada tumbuh kembang anak usia dini. Melainkan lebih pada penerapan pembelajaran di ruang kelasnya saja, belum meranah ke luar kelas. Padahal dalam mewujudkan pendidikan karakter, dibutuhkan keseimbangan pendidikan antara di dalam kelas (lembaga) dan di luar kelas (keluarga).

Apalagi pada situasi dan kondisi seperti saat ini yang menyaratkan pembelajaran menggunakan metode daring atau jarak jauh, pasti sangat berimplikasi pada menurunnya segala aspek anak usia dini yang seharusnya dapat tercapai ketika bertatap muka. Namun hal tersebut sekarang sulit untuk terealisasi karena pembelajaran diadakan dari rumah. Lembaga Pendidikan Anak Usia Dini yang awalnya melakukan stimulasi perkembangan anak usia dini melalui kegiatan belajar dan bermain di ruang kelas, karena sebab Covid-19 pembelajaran beralih di rumah masing-masing peserta didik secara daring. Dalam sebuah penelitian menyatakan bahwa 4 dari 10 guru di Taman Kanak-kanak masih belum siap jika pembelajaran dilakukan dengan daring. Hal ini dipengaruhi oleh fasilitas yang kurang memadai dari pihak guru dan orang tua dan masih adanya anggapan bahwa pembelajaran daring ini sulit dilakukan (Ayuni et al., 2021). Padahal kesiapan melakukan pembelajaran daring pada masa pandemi Covid-19 ini sangat diperlukan. Hasil penelitian lain menunjukkan kurang memadainya sarana dan prasarana dalam pembelajaran daring menyebabkan kurang maksimalnya materi yang disampaikan. (Kurniati et al., 2021). Sehingga hal yang harus disiapkan di antaranya yaitu rencana pembelajaran yang 
tepat, mengkomunikasikan dengan orang tua dan meningkatkan fasilitas pendukung lainnya (Ayuni et al., 2021).

Pembelajaran daring merupakan sistem pembelajaran yang harus dikaji dan diteliti dengan seksama dan mendalam. Hal ini bertujuan agar aspek dari pembelajaran anak usia dini tidak terabaikan. Hal seperti ini juga dapat berdampak terhadap potensi awal dan tumbuh kembang anak. Apabila ini dibiarkan terlalu lama, maka anak bukan tidak mungkin dapat kehilangan pondasi belajar dan kesiapan mengikuti pendidikan di tingkat lanjut. Sebenarnya proses pendidikan daring ini bukanlah hal yang baru di era revolusi industri 4.0 saat ini. Karena sejak awal masuk era digital sudah diperkenalkan tentang bagaimana dan apa saja hal-hal yang diperlukan dalam menghadapi era tersebut. Misalnya melalui pendidikan yang dapat membentuk generasi kreatif, inovatif dan kompetitif (Lase, 2019). Hal tersebut dapat tercapai dengan cara mengoptimalisasi penggunaan teknologi dan informasi terbaru sebagai alat bantu pendidikan. Sehingga diharapkan mampu menghasilkan output peserta didik yang dapat mengikuti perubahan zaman (Satrianingrum et al., 2021).

Pendidikan daring adalah bentuk transformasi pendidikan tatap muka ke dalam bentuk dalam jaringan digital yang pasti memiliki tantangan yang berat bagi pendidik maupun peserta didik. Namun di sisi lain pendidikan daring juga memiliki peluang sekaligus manfaat yang positif bagi lembaga PAUD. Sehingga banyak lembaga PAUD yang menerapkan strategi khusus dalam melaksanakan proses pembelajaran di masa pandemi Covid-19 sekaligus melihat dan menangkap berbagai peluang yang mampu untuk dimanfaatkan guna peningkatan mutu pengelolaan pembelajaran agar lebih baik daripada sebelumnya. Proses perumusan, pelaksanaan dan evaluasi pada keputusan-keputusan lintas fungsi dalam sebuah pengelolaan pembelajaran ini lah yang kemudian disebut dengan manajemen strategi pembelajaran.

Menurut Husein Umar dalam Taufiqurokhman, 2016) manajemen strategi merupakan seni dan ilmu dalam hal pembuatan (formulating), penerapan (implementing) dan evaluasi (evaluating) keputusan-keputusan strategis antara fungsi yang memungkinkan sebuah organisasi mencapai tujuannya di masa mendatang. Manajemen strategi ini kemudian diimplementasikan untuk mengelola pembelajaran agar sesuai dengan tujuan yang telah direncanakan. Untuk mencapai pendidikan yang berkualitas dan berdaya saing maka diperlukan manajemen strategi seperti ini di dalam lingkup pendidikan, termasuk pembelajaran. Apalagi dengan adanya pembelajaran daring mengharuskan lembaga pendidikan memiliki formula tersendiri yang harus disiapkan untuk mengatasi berbagai permasalahan di dalam proses 
pembelajaran. Ini lah yang kemudian dilakukan oleh TK Pertiwi 4 Desa Giripurno Kecamatan Borobudur Kabupaten Magelang Jawa Tengah. Lembaga PAUD ini telah menyiapkan manajemen strategi khusus sebagai bentuk improvisasi di masa pandemi Covid-19 agar pelaksanaan pembelajaran di lembaga tersebut dapat berjalan sesuai dengan target dan standar kebutuhan aspek anak usia dini.

TK Pertiwi 4 Giripurno Borobudur merupakan salah satu dari lembaga pendidikan di bawah naungan Yayasan Dian Dharma Magelang. Lembaga TK ini mendapatkan izin operasional sejak tahun 2006. Sebagai lembaga AUD bercorak umum (bukan keagamaan) TK Pertiwi 4 Giripurno menyelenggarakan kegiatan pembelajaran dengan kurikulum 2013 PAUD. Di lembaga PAUD ini siswa diberikan pengalaman belajar seluas-luasnya untuk mengembangkan kemampuan berupa sikap, pengetahuan dan keterampilan sesuai enam aspek AUD dalam Permendikbud Nomor 137 tahun 2013 yaitu, (1) nilai agama dan moral, (2) fisikmotorik, (3) kognitif, (4) bahasa, (5) sosial-emosional dan (6) seni.

TK Pertiwi 4 Giripurno berlokasi di kawasan wisata Balkondes Candi Borobudur Magelang, sehingga lembaga ini memiliki berbagai program pembelajaran yang unik di banding lembaga AUD lain. Hal ini dibuktikan dengan adanya program pembelajaran menggunakan media alam setiap dua kali dalam seminggu yang memanfaatkan sarana dan prasarana Balkondes Giripurno Borobudur (Reni Destiningsih, 2020). Program ini merupakan kebijakan dari kepala sekolah sebagai langkah strategis dalam rangka mengintegrasikan pembelajaran kelas dan luar kelas serta sebagai wujud kepedulian dalam meningkatkan daya tarik wisatawan asing agar tertarik ke Desa Giripurno. Dengan demikian secara tidak langsung akan berimplikasi pada eksistensi sekaligus sosialisasi lembaga tersebut.

Manajemen lembaga di TK Pertiwi 4 Giripurno sudah baik dan tersistem. Peran kepala sekolah di lembaga AUD ini sangat penting dalam pengelolaan lembaga pendidikan, mulai dari perencanaan, pelaksanaan hingga evaluasi. Implementasi manajemen lembaga di sini tidak hanya untuk meningkatkan mutu pendidikan, tetapi sebagai wujud strategi dalam melaksanakan pembelajaran. Manajemen strategi pembelajaran dibutuhkan mengingat TK Pertiwi 4 Giripurno berada dalam salah satu desa rawan bencana alam Gunung Merapi. Jarak Gunung Merapi dengan desa-desa di kawasan Borobudur sekitar 27,7 km. Maka dari itu diperlukan strategi khusus dalam menangani risiko dari bencana meletusnya Gunung Merapi yang dapat berimplikasi pada terganggunya proses pembelajaran. Hal ini yang menjadikan manajemen risiko dibutuhkan oleh TK Pertiwi 4 Giripurno untuk mengatasi berbagai risiko yang sewaktu- 
waktu dapat terjadi. Oleh karenanya, pada masa pandemi Covid-19 lembaga AUD ini telah memiliki manajemen strategi pembelajaran yang baik. Kepala sekolah cukup melakukan sedikit improvisasi terhadap kebijakan sekolah dengan menyesuaikan kebijakan pembelajaran dari pemerintah.

Berbagai penelitian terkait strategi pembelajaran di masa pandemi Covid-19 telah berjalan, namun belum ditemukan hasil penelitian yang mengungkap manajemen strategi pembelajaran di masa pandemi utamanya dalam menganalisis manajemen risiko. Seperti penelitian (Ali Murfi, 2020) tentang "Kepemimpinan Kepala Sekolah dalam Situasi Krisis Covid-19 di Indonesia” yang menyoroti tentang peran kepala sekolah di lembaga pendidikan dalam menyikapi dan mengambil keputusan dalam situasi krisis di masa pandemi Covid-19. Namun subjek dan obyek penelitian tersebut dilakukan di Sekolah Islam Al-Azhar Cairo Yogyakarta. Sementara artikel ini menunjukkan hasil penelitian yang bersubjek dan obyek penelitian pada lembaga anak usia dini TK Pertiwi 4 Giripurno Borobudur Magelang. Penelitian lainnya dari (Nurhasanah, 2020) tentang "Peran Orang Tua dalam Pendampingan Belajar Anak pada Masa Pandemi Covid-19 di TK Kemala Bhayangkari Bone", yang memaparkan terkait peran penting orang tua dalam mendampingi proses pembelajaran anak TK dalam rangka mencegah dari dampak negatif gadget dan implikasi digitalisasi. Namun penelitian ini belum mengarah kepada manajemen strategi pembelajaran di lembaga, karena hanya berbicara tentang pada peran orang tua dalam pembelajaran bukan peran lembaga. Selain itu penelitian yang dilakukan oleh (Ika Rifngatin, 2020) tentang Manajemen Pembelajaran Anak Usia Dini Saat Pandemi Covid-19, menghasilkan penelitian terkait manajemen pembelajaran yang dilakukan oleh RA Amanah Ummah 8 Bener Klaten di era Covid-19. Akan tetapi penelitian tersebut belum menunjukkan implementasi dari manajemen strategi dalam pembelajaran di era Covid19 sebagaimana yang diinginkan dalam riset ini.

Hasil penelitian diharapkan dapat dimanfaatkan untuk menyempurnakan kebijakan pembelajaran daring sekaligus sebagai sebuah pijakan manajemen strategi dalam pembelajaran di tengah berbagai risiko yang sewaktu-waktu dapat terjadi di masa depan. Oleh karena itu penelitian ini penting untuk dilakukan guna mengetahui implementasi dari manajemen strategi pembelajaran yang dilakukan oleh lembaga pendidikan anak usia dini, di TK Pertiwi 4 Giripurno Borobudur. Penelitian ini memfokuskan kajian pada manajemen strategi lembaga pendidikan anak usia dini dalam pelaksanaan pembelajaran di masa pandemi Covid-19. Fakta yang ada di masyarakat, orang tua peserta didik mengeluhkan anak-anaknya yang belum dapat 
memperoleh hasil yang maksimal dalam proses pembelajaran daring (jarak jauh). Oleh karenanya, penelitian terkait manajemen lembaga menjadi hal yang sangat penting sebagai suatu strategi dalam meningkatkan kualitas mutu pembelajaran pada berbagai situasi dan kondisi.

\section{METODE PENELITIAN}

Penelitian ini menggunakan metode penelitian kualitatif dengan pendekatan studi kasus. Penelitian ini menyajikan data sesuai dengan hasil penelitian yang diperoleh dari subyek penelitian di lapangan. Informasi yang diperoleh dengan cara observasi langsung ke lapangan sesuai pokok penelitian. Penelitian kualitatif berusaha untuk mengangkat secara ideografis berbagai fenomena dan realitas sosial. Pembangunan dan pengembangan teori sosial khususnya sosiologi dapat dibentuk dari empiri melalui berbagai fenomena atau kasus yang diteliti. Dengan demikian teori yang dihasilkan mendapatkan pijakan yang kuat pada realitas, bersifat kontekstual dan historis. Metode penelitian kualitatif membuka ruang yang cukup bagi dialog ilmu dalam konteks yang berbeda, terutama apabila ia difahami secara mendalam dan tepat (Somantri, 2005).

Penelitian ini dilakukan dengan mengeksplorasi secara menyeluruh tentang fenomena di TK Pertiwi 4 Giripurno Borobudur yang mempunyai karakteristik khas, langka dan bernilai strategis. Kegiatan eksplorasi melalui studi kasus dilakukan ketika topiknya luas dan konteksnya kompleks (Hak, n.d.). Penelitian kualitatif yang dilakukan bersifat deskriptif dan cenderung menggunakan analisis pendekatan induktif, sehingga makna dan prosesnya berdasarkan perspektif subyek lebih ditonjolkan (Fadli, 2021). Penelitian ini menghendaki kejadian-kejadian alamiah secara fokus, bukan kejadian yang dikondisikan (Kothari, 2004). Sementara Creswell menjelaskan bahwa studi kasus merupakan metode penelitian yang menyelediki secara cermat suatu peristiwa, program, aktivitas sekelompok orang dan dibatasi oleh waktu serta aktivitas informan (Creswell, 2016).

Penggunaan metode ini digunakan untuk memperoleh pemahaman mendalam tentang manajemen strategi lembaga pendidikan anak usia dini di TK Pertiwi 4 Desa Giripurno Kecamatan Borobudur Kabupaten Magelang dalam pelaksanaan pembelajaran di masa pandemi Covid-19. TK Pertiwi 4 Giripurno merupakan salah satu lembaga PAUD yang memiliki strategi khusus dalam pengelolaan lembaganya guna memperlancar kegiatan belajar mengajar di era pandemi Covid-19. Melalui manajemen strategi yang baik, maka dapat 
memenuhi enam aspek perkembangan anak usia dini yang terdiri atas (1) nilai agama dan moral, (2) fisik-motorik, (3) kognitif, (4) bahasa, (5) sosial-emosional dan (6) seni. Selanjutnya hasil temuan penelitian ini dideskripsikan melalui bahasa yang sistematis dan komprehensif sesuai fakta penelitian yang ada di lapangan.

Lokasi dalam penelitian ini dilakukan di TK Pertiwi 4 Giripurno yang beralamat di Desa Giripurno Kecamatan Borobudur Kabupaten Magelang Jawa Tengah. Sementara waktu pelaksanaan penelitian dilakukan selama enam bulan, dimulai setelah satu bulan diberlakukan larangan untuk berkumpul (social distancing) dan diberlakukan Pembelajaran Jarak Jauh (PJJ), yakni bulan Juni sampai dengan bulan November 2020. Di mana pada kondisi tersebut diwajibkan oleh Pemerintah agar seluruh proses pendidikan dan pengajaran dilakukan secara virtual atau daring. Sehingga seluruh peserta didik melaksanakan pembelajaran dari rumah masing-masing. Adapun objek penelitian ini yaitu manajemen strategi atau kebijakan yang ditempuh oleh lembaga PAUD TK Pertiwi 4 Desa Giripurno Borobudur Magelang di masa pandemi Covid-19.

Teknik pengumpulan data dilakukan dengan wawancara, observasi dan dokumentasi. Wawancara dan dokumentasi menjadi pokok utama dalam proses pengumpulan data, dikarenakan kondisi pandemi maka observasi hanya dapat dilakukan secara partial obervation. Informan yang menjadi sumber dalam hal ini berjumlah 5 orang, terdiri dari 1 kepala sekolah, 2 dewan guru dan 2 orang tua siswa. Data yang terkumpul kemudian dianalisis menggunakan langkah reduksi data, penyajian data, penarikan kesimpulan dan verifikasi. Pengujian keabsahan data dilakukan dengan tringulasi sumber, teknik dan waktu. Tringulasi sumber dilaksanakan dengan cara pengecekan secara ulang melalui teknik wawancara kepada sumber lain dengan pertanyaan yang sama untuk mengkonfirmasi informasi satu dengan lainnya. Kemudian dilakukan juga tringulasi teknik dalam rangka mengkomparasikan informasi hasil wawancara pertama dengan informasi selanjutnya guna menguji kredibilitas data. Sementara tringilasi waktu dilakukan untuk menguji data secara berulang guna menemukan data yang relevan sesuai pertanyaan dalam topik penelitian.

\section{HASIL DAN PEMBAHASAN}

\section{A. Hasil}

Manajemen merupakan proses kerjasama untuk mencapai tujuan yang telah ditetapkan melalui proses perencanaan, pengorganisasian, penggerakan dan pengontrolan sehingga tujuan 
yang diinginkan dapat tercapai (Sutarman, 2015). Sebagai lembaga pendidikan anak usia dini yang masih dalam proses peningkatan mutu, TK Pertiwi 4 Giripurno Borobudur menyusun manajemen strategi guna melancarkan pelaksanaan pembelajaran di masa pandemi Covid-19. Menurut (Winarni, 2020) selaku Kepala Sekolah TK Pertiwi 4 Giripurno, lembaga PAUD pimpinannya tersebut merupakan salah satu dari beberapa TK Pertiwi di Kabupaten Magelang yang pengelolaan lembaga pendidikannya sedang proses menuju peningkatan kualitas mutu pembelajaran. Hal ini terlihat dari adanya pengelolaan proses pembelajaran yang telah dilakukan sejak beberapa tahun 2018, misalnya dengan menyusun perencanaan pembelajaran baik Rencana Pelaksanaan Pembelajaran Harian (RPPH) maupun Rencana Pelaksanaan Pembelajaran Mingguan (RPPM) dengan mengacu Kurikulum PAUD 2013.

Kepala Sekolah di lembaga PAUD tersebut berperan dalam mengelola pembelajaran, mulai dari awal perencanaan, proses pelaksanaan, pengawasan dan evaluasi. Dengan adanya peran dari kepala sekolah terkait keterlibatannya dalam pelaksanaan pembelajaran di TK diharapkan hasil pembelajaran para peserta didik dapat tercapai sesuai dengan visi dan misi dari lembaga (Novi Kurnia Sari, 2020). Sejak berdiri pada tahun 2006 dengan Nomor SK Operasional 421.2/1654/12.2d/2006, TK Pertiwi 4 Giripurno telah terdaftar sebagai lembaga pendidikan formal yang terakreditasi BAN PAUD. Saat ini predikat akreditasi TK Pertiwi 4 Giripurno telah mencapai predikat baik. Tentunya ini menunjukkan hasil pengelolaan yang cukup baik di tingkat lembaga PAUD, mengingat pada akreditasi pertama pada 07 November 2008 mendapat predikat C. Namun seiring dengan peningkatan kualitas SDM sebagai pengelola sekaligus pendidik di sana, lembaga ini lambat laun mengalami perkembangan dalam hal manajerial.

Berdasarkan hasil observasi TK Pertiwi 4 pertanggal 05 Agustus 2020 yang beralamatkan di RT 01 RW 01 Dusun Gayam Desa Giripurno Kecamatan Borobudur Kabupaten Magelang, dari seluruh peserta didik di kelas A yang berjumlah 45, pendapatan ekonomi orang tuanya rata-rata kurang dari Rp 1.500 .000 per bulan menurut database (Dokumen TK Pertiwi 4 Giripurno, 2020). Pendapatan tersebut masih cukup jauh tertinggal di bawah Upah Minimum Kabupaten/Kotamadya (UMK) Magelang Rp 2.042.200 (Gubernur, 2019). Sehingga ketika menghadapi situasi pandemi Covid-19 di tahun 2020, tidak sedikit dari orang tua peserta didik yang terbebani dengan pembayaran SPP anaknya di sekolah.

Menurut Choirunisa selaku pendidik di TK Pertiwi 4 Giripurno mengatakan dampak dari pandemi Covid-19 dapat dirasakan oleh para orang tua peserta didik sekaligus guru dan 
masyarakat di lingkungan lembaga. Menurutnya dampak ekonomi sangat dirasakan oleh orang tua peserta didik mengingat pekerjaan sehari-hari mereka harus dihentikan karena pandemi. Sebagaimana tersebut dalam dokumen database lembaga bahwa penghasilan orang tua di TK ini rata-rata masih di bawah Upah Minimum Kabupaten (UMK), sehingga untuk mengatasi hal tersebut pimpinan lembaga melalui kebijakan Kemendikbud menggunakan dana Bantuan Operasional Sekolah (BOS) dan Bantuan Operasional Pendidikan (BOP) PAUD sebagai dana pendidikan agar proses pembelajaran tetap berjalan. Implementasi kebijakan dari pemerintah terkait dana pendidikan ini menurut Winarni, selaku kepala TK, sangat membantu lembaga dalam proses pelaksanaan pembelajaran di era Covid-19. Penggunaan dana seperti BOS dan BOP PAUD untuk sekolah menurutnya mampu mengatasi problem-problem keuangan lembaga pendidikan seperti di TK Pertiwi 4 Giripurno dalam rangka kelancaran program pembelajaran di sana.

Peran kepala TK Pertiwi 4 Giripurno dalam mengelola strategi pembelajaran di masa pandemi juga sangat baik. Hal ini dapat dibuktikan dari integritas dan kredibilitasnya dalam merencanakan penggunaan dana bantuan dari pemerintah untuk lembaga sesuai Perpres Nomor 54 tahun 2020. Misalnya, kepala sekolah memimpin langsung rapat koordinasi perencanaan dana pendidikan sebagai salah satu strategi pembelajaran di lembaga AUD tersebut. Ia menyesuaikan Dana Alokasi Khusus (DAK) Nonfisik Bidang Pendidikan sesuai dengan Perpres No. 54 tahun 2020 sekaligus disesuaikan dengan kebutuhan untuk pengadaan fasilitas atau infrastruktur pembelajaran digital di lembaganya. Di sisi lain sebagai kepala TK, Winarni tidak mengurangi hak dari apa yang harus diperoleh pendidik. Dalam menangani kekurangan dana untuk proses pembelajaran, kepala sekolah juga membuat kebijakan pemotongan biaya pembelajaran 40-50\% per anak disesuaikan dengan kemampuan keuangan orang tua siswa. Menurutnya melalui strategi tersebut pelaksanaan proses pembelajaran di TK Pertiwi 4 Giripurno tetap berjalan sesuai dengan perencanaan dan program kerja yang telah ditetapkan di awal.

Namun demikian adanya perbedaan penghasilan ekonomi orang tua siswa di TK Pertiwi 4 Giripurno juga menjadi problem oleh beberapa orang tua siswa. Hal ini selaras dengan teori Matthew J. Easterbrook bahwa ketidaksetaraan historis dalam masyarakat dapat berimplikasi pada penderitaan beberapa kelompok siswa. Menurut Matthew kesenjangan yang terjadi secara tidak proporsional tersebut menjadi hambatan psikologis terhadap keberhasilan pendidikan. Sehingga pada akhirnya memberikan kontribusi yang besar terhadap ketidaksetaraan dalam 
hasil pendidikan antara siswa satu dengan lainnya. Serangkaian intervensi psikologis yang bijaksana menurut Matthew dapat membantu menghilangkan hambatan ini dengan menargetkan interpretasi subyektif siswa dari konteks pendidikan lokal mereka (Easterbrook \& Hadden, 2021). Akan tetapi menurut Novi sebagai pendidik yang sekaligus operator TK Pertiwi 4 Giripurno mengatakan bahwa ketidaksetaraan penghasilan ekonomi dari orang tua yang menjadi problem ini telah diselesaikan melalui kebijakan kepala sekolah yaitu dengan memberikan diskon hingga 50\% kepada orang tua siswa sesuai penghasilannya masing-masing.

Masa pandemi Covid-19 juga berdampak pada sistem pembelajaran di TK Pertiwi 4 Giripurno Borobudur yang awalnya normal melalui sistem tatap muka, selanjutnya pembelajaran dilakukan secara daring atau online melalui jaringan internet. Dengan diberlakukannya pembelajaran daring pada awalnya sebagian besar orang tua merasa tidak siap. Sebagaimana disampaikan oleh (Nuryah, 2020) salah satu orang tua siswa di TK Pertiwi 4 Giripurno, ia mengatakan bahwa dalam melaksanakan proses pembelajaran jarak jauh melalui daring lebih sulit dilakukan. Selain karena anak belum terbiasa pembelajaran secara formal di lingkungan keluarga secara langsung di bawah pengawasan orang tua, tidak sedikit juga di antara orang tua yang tidak bisa mengoperasionalkan pembelajaran online. Sebagian orang tua terutama mereka yang berusia cukup lanjut dan atau bagi kakek nenek yang diamanahi cucu yang sekolah di TK kesulitan melaksanakan proses PJJ. Menurut (Dewi, 2020) sebagai salah satu orang tua siswa yang merasa keberatan dengan pelaksanaan belajar daring mengatakan kesulitannya dalam mengatur anaknya ketika proses pembelajaran di rumah. Apalagi ia juga memiliki anak berusia SD dan SMP yang juga membutuhkan pendampingan khusus dalam proses pembelajaran daring. Sehingga menurutnya di masa pandemi Covid-19 ini membutuhkan kebijakan khusus dari lembaga sebagai langkah strategis dalam mengatasi problem pembelajaran di masa pandemi, utamanya bagi anak usia dini.

Pemerintah dalam hal ini Kementerian Pendidikan dan Kebudayaan belum mengambil langkah tegas terkait bagaimana sistem dan strategi pembelajaran secara detail di lembagalembaga pendidikan, khususnya PAUD. Oleh sebab itu menurut Kepala Sekolah TK Pertiwi 4 mereka telah mengadakan rapat koordinasi dengan pihak manajemen lembaga dan berbagai unit terkait untuk mengambil kebijakan khusus sebagai manajemen strategi dalam rangka kelancaran pembelajaran. Beberapa strategi yang dilakukan kepala sekolah dalam mengelola krisis pembelajaran di era pandemi di antaranya dengan meningkatkan koordinasi dengan orang tua siswa. Hal ini selaras dengan teori hubungan masyarakat PAUD yaitu bahwa melakukan 
koordinasi dengan orang tua siswa sangat penting dilakukan agar ketika siswa sedang di rumah mereka dapat menjadi pembimbing, pengarah, pendidik, pengembang dan pengawas (Kurniati et al., 2021).

Pada masa pandemi peran orang tua sangat penting dalam menghilangkan rasa canggung anak dalam bertemu orang-orang baru di sekitarnya, terutama teman sebaya di desanya. Ini penting agar tumbuh kembang anak tidak terhambat dan upaya pendidikan dalam keluarga tercapai. Kesadaran orang tua tentang pentingnya pendidikan anak usia dini sangatlah penting karena mereka mempunyai peranan yang penting dalam mendidik anak (Adhimah, 2020). Orang tua menjadi salah satu pihak yang bertanggung jawab dalam keberlangsungan pendidikan anak usia dini di masa Covid-19 (Fariq et al., 2021; Kahar, n.d.). Orang tua berperan dalam merangsang dan memfasilitasi seluruh perkembangan aspek anak (Agus Jatmiko, 2020). Di samping keterlibatan orang tua, pengelolaan pendidikan juga dibutuhkan manajemen strategi yang baik. Di TK Pertiwi 4 Giripurno kepala sekolah telah melibatkan orang tua dan manajemen lembaga dalam rangka menyusun strategi sebagai bagian dari manajemen strategi dalam pembelajaran di masa pandemi Covid-19.

Jika dilihat secara epistemologi manajemen strategi sendiri merupakan serangkaian keputusan dan tindakan pengelolaan yang mampu menentukan kinerja suatu organisasi dalam jangka waktu yang panjang. Artinya suatu organisasi seperti lembaga pendidikan dapat menganalisis peluang dan tantangan bahkan ancaman beberapa tahun mendatang. Sehingga ketika terjadi suatu problem pendidikan sebagaimana pandemi Covid-19 saat ini akan segera dapat teratasi. Tokoh utama yang menjadi pengelola dalam memangku kebijakan sekaligus pelaksana manajemen strategi adalah kepala sekolah. Setidaknya terdapat lima hal mendasar tugas dan kewajiban yang menentukan keberhasilan kepala sekolah, yaitu program pengajaran, kesiswaan, para guru, tenaga fungsional yang lain dan tenaga administrasi, sarana dan prasarana sekolah dan hubungan atau kerjasama antara sekolah dengan masyarakat (Abdul Aziz, 2021). Maka dalam pelaksanaan manajemen strategi di lembaga tidak hanya mengedepankan kepala sekolah, melainkan peran serta masyarakat juga dibutuhkan, terutama komite dan orang tua siswa. Ini lah yang dilakukan oleh lembaga AUD di TK Pertiwi 4 Giripurno Borobudur yang selalu melibatkan komite dan orang tua siswa dalam rangka mengelola kebijakan pendidikan di lembaganya. Dengan demikian proses pembelajaran di lembaga AUD tersebut dapat tercapai sesuai dengan tujuan yang telah direncanakan. 


\section{B. Pembahasan}

Untuk mengembangkan pendidikan secara menyeluruh, manajemen pendidikan harus diprioritaskan dalam rangka kelangsungan lembaga pendidikan sehingga menghasilkan output yang diinginkan (Sutarman, 2015). TK Pertiwi 4 Giripurno Borobudur telah menerapkan manajemen strategi yang meliputi empat hal, yaitu perencanaan (planning), pengorganisasian (organizing), pelaksanaan (actuating) dan pengawasan (controlling). Teori manajemen tersebut yang selanjutnya dikenal dengan teori POAC tertulis dalam buku (Takale, 2013). Berikut ini bagaimana manajemen strategi diimplementasikan di lembaga pendidikan anak usia dini TK Pertiwi 4 Giripurno Borobudur dalam rangka pelaksanaan pembelajaran di masa pandemi Coronavirus Disase 2019 (Covid-19).

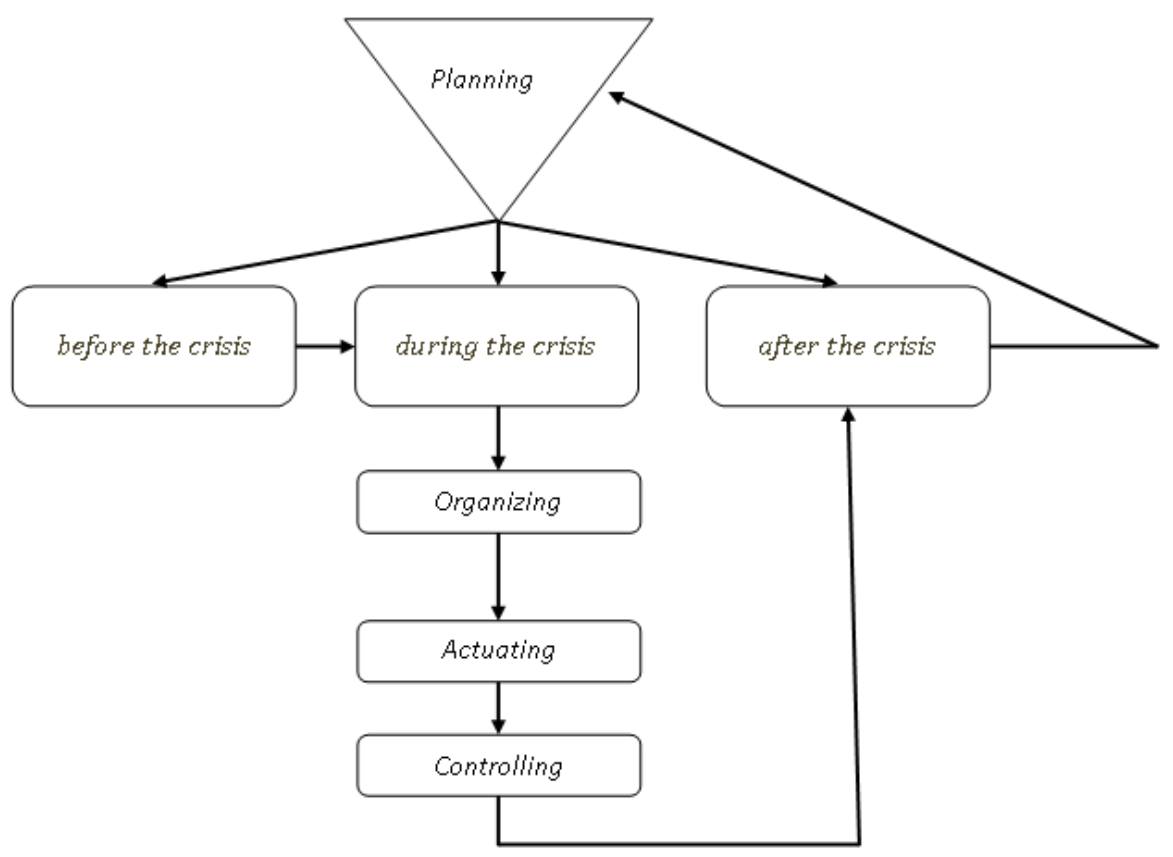

Gambar 1. Flowchart Manajemen Lembaga TK Pertiwi 4 Giripurno Borobudur

Pertama, tahap planning (perencanaan). Perencanaan merupakan kegiatan yang paling mendasar dalam kegiatan manajerial yang di dalamnya terdapat berbagai strategi dan upaya yang sistematis dalam rangka mencapai suatu tujuan yang telah diharapkan. Sehingga dalam membuat sekaligus menetapkan keputusan terkait kegiatan pembelajaran, pengelola lembaga yang dalam hal ini kepala sekolah harus menyiapkan berbagai alternatif untuk menjadi pilihan dalam rangka meraih tujuan.

TK Pertiwi 4 Giripurno Borobudur menyiapkan perencanaan krisis yang terdiri atas tiga hal, pertama, sebelum krisis (before the crisis); kedua, selama krisis terjadi (during the crisis), 
dan ketiga setelah krisis (after the crisis). Manajemen krisis ini berfungsi untuk memberikan keputusan yang tepat dalam mengambil tindakan ketika lembaga pendidikan menghadapi situasi yang kritis (Hough \& Spillan, 2011). Dengan menerapkan perencanaan krisis tersebut, TK Pertiwi 4 mampu meminimalisasi dan mengendalikan adanya dampak pembelajaran akibat Covid-19. Tidak hanya dampak pandemi dalam bidang pembelajaran, melainkan perihal ekonomi dan sosial juga mampu ditanggulangi. Dalam bidang ekonomi misalnya, telah dilakukan perencanaan secara komprehensif terkait dana pendidikan dari BOS dan DOP PAUD agar dialokasikan untuk fasilitas pembelajaran daring. Sehingga proses pembelajaran tetap berjalan sesuai rencana walaupun kondisi keuangan lembaga sedang kesulitan. Di sinilah perencanaan pembelajaran dilakukan oleh TK Pertiwi 4 Giripurno dalam rangka mengelola strategi pembelajaran di era pandemi Covid-19.

Kedua, tahap pengorganisasian. Pengorganisasian dalam lembaga pendidikan difungsikan untuk mengelola tugas pokok dan fungsi dari masing-masing pegawai, baik tenaga pendidik maupun tenaga kependidikan. Tahap pengorganisasian di TK Pertiwi 4 Giripurno Borobudur dilakukan dengan cara pembagian SDM sesuai dengan kompetensi dan kapabilitasnya. Pembagian ini dilakukan melalui proses demokrasi yang dipimpin langsung oleh kepala sekolah dan dihadiri seluruh pegawai dan stakeholder internal. Di dalamnya dilakukan penunjukkan terhadap SDM yang mumpuni di bidang manajemen krisis. Sehingga selama krisis terjadi akan dapat terkelola dengan baik, bahkan kegiatan pembelajaran akan tetap terlaksana tanpa ada implikasi yang besar.

Proses pengorganisasian dalam lembaga PAUD sangat penting untuk dilakukan. Hal ini karena segala hal yang tidak terduga dapat terjadi kapan pun dan di mana saja. Ia tidak mengenal situasi dan kondisi subyek pembelajar, termasuk dalam hal ini anak-anak yang menjadi korban. Padahal anak-anak merupakan aset berharga bangsa ini ke depan. Di usia emas (golden age) sudah seharusnya ia memperoleh hak pendidikan sejak dini yang dilaksanakan secara berkelanjutan, dan tidak boleh berhenti. Apabila proses pembelajaran pada anak terhenti, sebagaimana halnya karena situasi pandemi Covid-19 saat ini, maka harus segera diberikan akses alternatif agar proses belajar tetap dapat dilaksanakan dengan lancar-tertib.

Demikian yang dilakukan TK Pertiwi 4 Giripurno, mereka telah mengimplementasikan manajemen risiko yanag baik di lembaganya. Sehingga walaupun dalam kondisi pandemi, kegiatan pembelajaran tetap berjalan dengan optimal karena telah memilih SDM khusus untuk menangani pencegahan penyebaran Covid-19 pada peserta didik dan pengurus lembaga. Di sini 
lah kemudian peran kepala sekolah menjadi sangat diperlukan untuk mengelola lembaganya. Sosok pemimpin merupakan aspek yang sangat berpengaruh dalam gerak dan hasil kinerja personalnya (Samsirin, 2015). Selain kepala sekolah, peran operator dan humas juga perlu ditingkatkan dalam kondisi krisis seperti ini. (Murfi \& Jannana, 2020).

Selanjutnya tahap ketiga, yaitu actuating (pelaksanaan). Setelah dilakukan pembagian antar SDM yang mumpuni di bidangnya dalam rapat koordinasi yang dipimpin langsung kepala sekolah bersama stakeholder, maka pada pelaksanaannya dilakukan dengan cara menyiapkan anggaran darurat dalam menangani during the crisis yang sewaktu-waktu dapat terjadi. Pada aplikasinya manajemen pembelajaran yang diimplementasikan para pendidik banyak menemui hambatan (Saifulloh \& Darwis, 2020). Dalam kondisi pandemi Covid-19 seperti saat ini, TK Pertiwi 4 Giripurno telah mengalokasikan anggaran khusus. Selain itu mereka juga telah menyiapkan SDM khusus untuk menangani krisis yaitu Gugus Pencegahan Penyebaran Covid19 yang bekerjasama dengan Bidan dan Klinik Desa Giripurno, serta Puskesmas di Kecamatan Borobudur. Salah satu keberhasilan lembaga PAUD ini dalam mengatasi krisis pendidikan di masa pandemi Covid-19 ini adalah karena kepala sekolah selalu menjauhi sikap ketergesaan.

Hal ini sesuai dengan ajaran dalam Serat Tajusalatin dalam (Pambudi, 2020), bahwa pemimpin harus menjauhi sikap ketergesaan. Keputusan yang diambil dalam kondisi tergesa merupakan tindakan yang ceroboh dan jauh dari ketelitian. Menurut serat Tajusalatin, keputusan yang bijaksana yaitu suatu keputusan yang berhasil ditentukan oleh seberapa jauh seorang pemimpin atau kepala dalam pengendalian diri, berhati-hati dan tidak tergesa-gesa. Selain itu, pemimpin juga harus dapat mengelola setiap krisis dan konflik yang ada. Dengan demikian kepala sekolah harus bersikap bijaksana, sabar dan bertanggung jawab atas segala hal yang telah diputuskan. Dalam pelaksanaan pembelajaran di tengah krisis pandemi Covid-19, TK Pertiwi 4 Giripurno telah membuat kebijakan pembelajaran secara berkelompok dan menyebar di masing-masing rumah peserta didik. Walau demikian, pendidikan di TK juga tetap dilaksanakan satu kali seminggu dengan sistem bergilir serta memakai prokes yang sangat ketat.

Tahap keempat, yaitu dilakukan pengawasan atau controlling. Dalam manajemen pendidikan fungsi pengawasan masuk dalam tindakan terakhir yang dilakukan pengelola suatu organisasi (Meriza, n.d.). Selain dilakukan pengawasan, pengamatan atau pemantauan terhadap pelaksanaan program kerja lembaga, di dalam controlling biasanya terdapat tahap evaluasi dan perbaikan. Pengawasan dilakukan oleh pendidik dalam rangka mencari sekaligus menganalisis informasi yang berkaitan dengan data-data kegiatan belajar agar dapat dievaluasi dengan baik. 
Setelah proses monev dilakukan, selanjutnya digunakan untuk mengontrol kegiatan pembelajaran dalam rangka mencapai target program belajar (Saifulloh \& Darwis, 2020). Pihak kepala sekolah juga memberikan supervisi untuk mengarahkan kinerja dan membimbing para guru di lembaga TK. Dengan melakukan supervisi para guru di sekolah akan lebih kolektif dan berkembang, sehingga tujuan pembelajaran sebagaimana terdapat di dalam kurikulum akan tercapai secara maksimal. Supervisi ini juga bertujuan untuk mengembangkan kegiatan iklim yang kondusif sehingga akan lebih baik dalam kegiatan proses pembelajaran (Mulya, 2019).

Proses pengawasan dan evaluasi tersebut juga dilaksanakan oleh TK Pertiwi 4 Giripurno Borobudur. Pengawas TK Pertiwi 4 Giripurno selalu memantau sekaligus mengarahkan agar kegiatan pembelajaran di masa pandemi Covid-19 tetap terlaksana, walaupun menggunakan protokol kesehatan yang sangat ketat. Misalnya ketika ada guru, murid atau bahkan orang tua peserta didik yang tidak mau mematuhi protokol kesehatan seperti menggunakan masker, mencuci tangan dan menjaga jarak, maka akan diingatkan secara tegas. Hal tersebut dilakukan untuk menjamin agar seluruh program kerja lembaga seperti proses pelaksanaan pembelajaran yang sedang berjalan dapat sesuai dengan perencanaan yang telah ditentukan di awal.

Selain melakukan pengawasan dan evaluasi terhadap proses pembelajaran, pimpinan lembaga PAUD melalui kepala sekolah juga berperan dalam melaksanakan monitoring dan evaluasi pada pencapaian kompetensi peserta didik. Pengawasan terhadap kompetensi peserta didik ini menyesuaikan dengan ketentuan perundang-undangan terkait situasi-kondisi kedaruratan Pandemi Covid-19. Ketentuan tersebut misalnya, penilaian hasil belajar tanpa harus melakukan perkumpulan siswa dan orang tua siswa; pemantauan penilaian dilakukan dengan cara berkomunikasi antara guru dengan orang tua atau wali siswa dan dalam pelaksanaan pembelajaran mengikuti kurikulum yang telah disusun oleh lembaga dengan tidak memaksa capaian kurikulumnya secara komprehensif, sehingga dalam penghitungan nilai raport nantinya pun menyesuaikan dengan kondisi darurat tersebut dengan tetap berpedoman pada ketentuan yang berlaku. Melalui manajemen strategi pembelajaran yang fleksibel, kredibel dan akuntabel tersebut TK Pertiwi 4 Giripurno Borobudur tetap dapat melaksanakan pembelajaran secara baik dan kondusif di tengah masa pandemi Covid-19 dan new normal.

Manajemen strategi sangat sesuai diimplementasikan oleh setiap tingkat lembaga pendidikan, khususnya pada tingkat PAUD. Walaupun secara praktis manajemen strategi seringkali digunakan oleh perusahaan yang notabene bergerak di bidang ekonomi, tetapi pada faktanya manajemen strategi juga dapat diaplikasikan untuk lembaga pendidikan sebagaimana 
telah dilakukan di TK Pertiwi 4 Giripurno Borobudur, utamanya dalam hal pembelajaran. Melalui manajemen strategi yang bertujuan untuk menumbuhkan dan mengatur strategi lembaga sejak dini, maka tujuan dari lembaga pendidikan dapat tercapai dengan baik dan tepat sesuai sasaran dan waktu yang telah ditetapkan. Melihat urgensi dari manajemen strategi tersebut, maka penting bagi lembaga pendidikan untuk menyiapkan sejak dini beberapa strategi dalam mengelola lembaganya sebagai antisipasi dari berbagai risiko yang sewaktu-waktu dapat terjadi seperti pandemi global Covid-19. Sehingga melalui implementasi strategi dari manajemen risiko yang terdiri atas before crisis, during crisis dan after crisis, maka berbagai problem terkait krisis dan risiko dapat ditangani dengan baik.

\section{SIMPULAN DAN SARAN}

Pandemi Covid-19 berimplikasi pada seluruh aktivitas kehidupan manusia mulai aktivitas olahraga, sosial, perkantoran, bahkan sampai pada hubungan spiritual-transedental bagi seluruh pemeluk agama di dunia, termasuk bidang pendidikan anak usia dini. Masa usia dini merupakan masa kecermelangan bagi tumbuh kembang anak, baik dari aspek kognitif, agama dan moral, sosial emosional, fisik motorik dan seni. Namun demikian, di masa pandemi Covid-19 seluruh aspek tersebut sulit untuk direalisasikan dalam pembelajaran karena diharuskan pembelajaran jarak jauh. TK Pertiwi 4 Giripurno Borobudur sebagai salah satu lembaga pendidikan anak usia dini yang terdampak krisis pandemi ini, memiliki strategi tersendiri dalam menghadapinya.

TK Pertiwi 4 Giripurno Borobudur menerapkan manajemen strategi pembelajaran sebagai cara dalam rangka memperlancar proses pembelajaran. Setidaknya ada empat strategi dalam mengelola pembelajaran di era pandemi, di antaranya yaitu implementasi perencanaan yang matang melalui analisis manajemen krisis (before crisis, during crisis dan after crisis), pengorganisasian (organizing) lembaga yang tersistem, pelaksanaan yang maksimal dan pemantauan (controlling) dengan menyesuaikan pada ketentuan perundang-undangan terkait situasi-kondisi kedaruratan pandemi Covid-19. Melalui implementasi manajamen strategi tersebut, maka dapat menjadi strategi yang cukup efektif dan efisien dalam mengendalikan proses pembelajaran walaupun di tengah kondisi krisis pandemi Covid-19. Penelitian ini diharapkan dapat menjadi referensi dalam meningkatkan manajemen risiko melalui berbagai strategi pengelolaan pembelajaran yang tepat di berbagai lembaga pendidikan anak usia dini. 
Sehingga ketika menghadapi pandemi maupun saat berada di dalam situasi kondisi yang tidak normal, maka pembelajaran dapat tetap berjalan dengan stabil sesuai target yang diharapkan.

\section{UCAPAN TERIMA KASIH}

Disampaikan terima kasih kepada Lembaga Penelitian dan Pengabdian kepada Masyarakat (LP2M) Sekolah Tinggi Agama Islam Nahdlatul Ulama (STAINU) Purworejo yang telah memfasilitasi penelitian ini bersama dengan tim peneliti dari Program Studi Pendidikan Islam Anak Usia Dini (PIAUD). Semoga hasil penelitian ini dapat bermanfaat dan dapat digunakan dalam praksis manajemen pendidikan pada lembaga PAUD di Indonesia.

\section{DAFTAR PUSTAKA}

Abdul Aziz. (2021). Peran Komite Sekolah Dalam Meningkatkan. 2, 19-34.

Adhimah, S. (2020). Jurnal Pendidikan Anak, Volume 9 ( 1 ), 2020, 57-62 Peran orang tua dalam menghilangkan rasa canggung anak usia dini ( studi kasus di desa karangbong rt . 06 rw. 02 Gedangan-Sidoarjo ). 9(20), 57-62.

Agus Jatmiko. (2020). Penerapan Evaluasi Pembelajaran Anak Usia Dini Universitas Islam Negeri Raden Intan Lampung , Bandar Lampung, Indonesia Begitu Pentingnya Pendidikan Anak Usia Dini Dalam Pengelolaan Pendidikan Masyarakat, Hingga Di Dunia Internasional Melihat Bahwa Sala. 3(1), 83-97.

Ayuni, D., Marini, T., Fauziddin, M., \& Pahrul, Y. (2021). Jurnal Obsesi : Jurnal Pendidikan Anak Usia Dini Kesiapan Guru TK Menghadapi Pembelajaran Daring Masa Abstrak. 5(1), 414-421. https://doi.org/10.31004/obsesi.v5i1.579

Creswell. (2016). Creswell - Educational Research Planning, Conducting and Evaluating.pdf. Easterbrook, M. J., \& Hadden, I. R. (2021). Tackling Educational Inequalities with Social Psychology: Identities, Contexts, and Interventions. 15(1), 180-236. https://doi.org/10.1111/sipr.12070

Fadli, M. R. (2021). Memahami desain metode penelitian kualitatif. Humanika, 21(1), 33-54. https://doi.org/10.21831/hum.v21i1.38075

Fariq, W. M., Darwis, M., Sofiani, I. K., \& Umar, A. N. (2021). Peran Orang T ua Dalam Mendidik Anak Perspektif Muhammad Taqī Al - Falsafī; Tela ' ah Kitab Al-Thifl Baina Al-Waratsah Wa Al-Tarbiyah The Role Of Parents In Educing Children's Perspective Muhammad Taqī Al-Falsafī; Have The Book Of Al -Thifl Baina Al-. 4(1), 106-123.

Fernandez, A. A., \& Shaw, G. P. (2020). Academic Leadership In A Time Of Crisis: The Corona And Virus - 1 9. 14(1), 39-45. https://doi.org/10.1002/jls.21684

Gubernur, S. (2019). Upah Bagr. 35.

Hak, J. D. \& T. (n.d.). Case Study metodology in business research (Vol. 148).

Haslam, S. A., Steffens, N. K., Reicher, S. D., \& Bentley, S. V. (2021). Identity Leadership in a Crisis : A 5R Framework for Learning from Responses to COVID-19. 15(1), 35-83. 
https://doi.org/10.1111/sipr.12075

Hough, M. G., \& Spillan, J. E. (2011). Crisis Planning: Increasing Effectiveness, Decreasing Discomfort. Journal of Business \& Economics Research (JBER), 3(4). https://doi.org/10.19030/jber.v3i4.2762

Kahar, M. I. (n.d.). Masa COVID-19 Gusnarib Wahab Fakultas Tarbiyah dan Ilmu Keguruan IAIN Palu Fakultas Tarbiyah dan Ilmu Keguruan IAIN Palu Pandemi covid-19 mempengaruhi semua aktivitas kehidupan manusia mulai aktivitas olahraga, perkantoran , bahkan sampai pada hubungan t. 49-66.

Kementrian Pendidikan, K. (2020). Pendidikan Kebudayaan. 021.

Kothari, C. R. (2004). Research Metodology.

Kurniati, E., Kusumanita, D., Alfaeni, N., \& Andriani, F. (2021). Jurnal Obsesi : Jurnal Pendidikan Anak Usia Dini Analisis Peran Orang Tua dalam Mendampingi Anak di Masa Abstrak. 5(1), 241-256. https://doi.org/10.31004/obsesi.v5i1.541

Lase, D. (2019). Jurnal sundermann.

Meriza, I. (n.d.). Pendidikan. 37-46.

Mulya, N. (2019). Supervisi Pusat Kegiatan Belajar Masyarakat ( Pkbm) Terhadap Kepala Sekolah Terkait Manajemen. 2(2), 47-60.

Murfi, A., \& Jannana, N. S. (2020). Kepemimpinan Sekolah dalam Situasi Krisis Covid-19 di Indonesia. 5(c), 119-136.

Pambudi, S. (2020). Filsafat Jawa: Belajar Menjadi Pemimpin Dalam Ajaran Serat Tajusalatin. II(1), 130-153.

Rodrigues, M., \& Franco, M. (2020). COVID-19 and Disruption in Management and Education Academics : Bibliometric Mapping and Analysis.

Saifulloh, A. M., \& Darwis, M. (2020). Manajemen Pembelajaran dalam Meningkatkan Efektivitas Proses Belajar Mengajar di Masa Pandemi Covid-19. Bidayatuna: Jurnal $\begin{array}{llll}\text { Pendidikan Guru } \quad \text { Mandrasah } & 285 .\end{array}$ https://doi.org/10.36835/bidayatuna.v3i2.638

Samsirin. (2015). Konsep Manajemen Pengawasan dalam Pendidikan Islam. At-Ta'dib, Vol. 10. $N, 341-360$.

Satrianingrum, A. P., Prasetyo, I., Anak, P., Dini, U., \& Yogyakarta, U. N. (2021). Jurnal Obsesi : Jurnal Pendidikan Anak Usia Dini Persepsi Guru Dampak Pandemi Covid-19 terhadap Pelaksanaan Pembelajaran Daring di PAUD Abstrak. 5(1), 633-640. https://doi.org/10.31004/obsesi.v5i1.574

Somantri, G. (2005). Memahami metode penelitian. 9(2), 57-65.

Stallman, C., Kieran, S., Quinn, D., \& Schaibley, V. M. (2021). Rethinking genetic counseling clinical skills training in the time of COVID- -. February, 1-6. https://doi.org/10.1002/jgc4.1503

Sutarman, M. (2015). Pendidikan Anak Usia Dini ( PAUD ) Holistik Integratif. 61-72.

Takale, 2013. (2013). Principles Of Management "They Say That Dedicating Is One Of The Most Beautiful Acts Of Love One Can Perform. I Would Argue That It Is Even More Beautiful To Dedicate This To You Without Saying My Name". 
Utomo, A. P. (2020). WHO Umumkan Nama Resmi untuk Virus Corona: Covid-19. https://internasional.kompas.com/read/2020/02/11/23170631/who-umumkan-namaresmi-untuk-virus-corona-covid-19

Wawancara dengan Nuryah Hikmawati pada 10 Agustus 2020

Wawancara dengan Dewi Masitoh pada 10 Agustus 2020

Wawancara dengan Novi Kurnia Sari pada 10 Juli 2020

Wawancara demgan Choirunisa pada 10 Juli 2020.

Wawancara demgan Winarni pada 10 Juli 2020. 